\title{
The additional protocol to the African Charter on Human and People's Rights: indications of capacity for African municipal systems
}

NKOLIKA IJEOMA ANIEKWU

Department of Public Law, University of Benin

\section{INTRODUCTION}

Since 1945 and the United Nations Charter, the United Nations has promoted human rights as essential to individual liberty, international peace and development. Major human rights treaties and documents include the International Covenant on Civil and Political Rights (ICCPR), the International Covenant on Economic, Social and Cultural Rights (ICESCR), the Convention on the Rights of the Child (CRC), the Convention against Torture and Other Cruel, Inhuman or Degrading Punishment, and the Convention on the Elimination of All Forms of Discrimination against Women (CEDAW). International and regional human rights discourse has centred on the protection of civil, political, economic, social and cultural rights; viz, the rights to equality and non-discrimination, freedom of expression, liberty, life, privacy, education, a clean environment, bodily integrity, religious and political beliefs, freedom from torture, degrading or inhuman treatment, freedom of movement, association, etc. The above human rights documents, including CEDAW, are legally binding under international law. However, unlike treaties or conventions, reports produced by conferences are considered 'consensus' documents or 'soft' law, as they only express political will but are not legally binding.

Until 1993 no international document included anything specific about sexuality. Prior to this time nothing was stated about the rights of persons to express their sexual orientations, preferences or desires. Even the famous 1979 CEDAW, popularly known as the International Bill of Rights for Women, endorsed sexual equality, women's right to control their fertility, and women's right to be free from violence and coercion, but was silent on any specific rights to sexual freedom or orientation. More importantly, it made no specific provisions for, or references to, African territories.

Despite its non-legal status, a major step for sexual rights came with the Vienna Declaration and Programme of Action at the Vienna World Conference on Human Rights in 1993, which introduced the idea of sexual rights 
as freedom from sexual coercion. In 1994 the International Conference on Population and Development (ICPD) explicitly acknowledged 'sexual health' as requiring that people are able to have a 'satisfying and safe sexual life'. The document conservatively situated sexual rights within a heteronormative and reproductive rights context, and there was no mention of sexual pleasure, freedom of sexual expression and freedom of sexual orientation. Again, the specific needs of women in developing countries, including the sub-Saharan African diaspora, were not addressed. Despite this, the ICPD was seen as a positive and significant step towards recognising sexual rights.

In Africa the struggle to legally recognise sexual rights as human rights remained. Within the domiciliary systems the debate over sexual rights issues continues to raise questions surrounding the 'legality' of sexual rights in different cultural, political and economic environments. Even though the widening of the rights debate and the opening of democratic space and governance in Africa have provided an opportunity for many Africans to renegotiate their sexualities in different ways, challenges to legality strongly persist in the various domiciliary systems. Religion, politics, gender stereotypes and culture further exacerbate the legal pertinence of these battles.

\section{HUMAN RIGHTS, CULTURAL RELATIVITY AND GENDER}

The question of the 'universal' (equal) or 'relative' (contingent) character of the rights declared in the major instruments of the human rights movement has been a source of debate and advocacy from the movement's start. The contest between these positions took on renewed vigour as the human rights movement slowly developed, and reneged on making specific provisions on gender issues. Significant developments emerged over the decades between claims associated with cultural relativism, on the one hand, and universalism, on the other, as they relate to gender in different territories. ${ }^{1}$ There have also been diverging theories on the sovereign autonomy of a state to follow its own paths in the above matters. For example, the universal theory of human rights claims that the rights to equality and equity enshrined in the international treaties must be applicable all over the world in the various domiciliary legal systems, even in societies that are fundamentally cultural, religious and/ or customary. ${ }^{2}$

On the other hand, advocates of cultural relativism posit that religious, moral and cultural rules are encoded in the whole theory of rights, and that rights, therefore, depend on a 'cultural' context; the term 'culture' often being used in a broad and diffuse way that reaches beyond indigenous traditions and customary practices to include political and religious ideologies and institutional distinctions. ${ }^{3}$ According to Ibidapo - Obe, 'human rights is fla-

1 See generally, Steiner J \& Alston P International human rights in context: Law, politics and morals (2000) 312 .

2 Steiner Henry J \& Alston P (n 1 above) 161.

3 Cook R 'Reservations to the Convention on the Elimination of All Forms of Discrimination against Women' (1990) 30 Virginia Journal of International Law 650. 
voured by the culture within which it is to be invoked...the perception of human rights is conditioned, in space and time, by a combination of historical, political, economic, social, cultural and religious factors'. ${ }^{4}$

Although human rights are mostly regarded as a 'radical' development in international law because of their challenge to traditional culture and the public/private dichotomy between states and individuals, the subject has retained a deeper, gendered distinction. In the major human rights treaties, a 'masculine' identity is often adopted, and rights are defined according to what men fear will happen to them; those harms against which they seek guarantees. The primacy traditionally given to civil and political rights by international lawyers and philosophers is directed towards human rights protection in public life, ie in relationships between state and government. The same importance has not generally been accorded to economic and social rights that generally affect life in the private sphere and the world of women.

The struggle to incorporate gender issues into international and regional agreements indicates how strategic efforts to use the law to promote women's human rights are constrained by political and legal contexts. Feminist and postcolonial theories have continued to struggle with the question of how to insert women's issues into a male-biased and/or purportedly neutral body of human rights law. Where equality is conceptualised as 'sameness', the law seems to impose a regime of formal equality, which on the face of it guarantees neutral treatment to both men and women. However, there is a hidden male bias in this model. According to this 'sameness' model, women (who do not conform to the male standard) are denied the fruits of equality. In emphasising the sameness of women and men, gender specificity and the 'woman's issue' are erased. This is not to say that when women are victims of human rights abuse they are not accorded protection, but most of these violations are not the harms from which women most need protection. For example, although racial discrimination consistently appears in many jus cogens inventories, human rights protection in issues concerning women's health, sexual equality and discrimination initially did not. ${ }^{5}$ It was only after the adoption of CEDAW that specific issues, such as gender equality, became firmly entrenched in a United Nations treaty document. ${ }^{6}$ This very important document however did not address the sexual health and rights of African women.

In Africa the treaties that provide for the protection of sexual rights are the African Charter on Human and People's Rights (the African Charter), which entered into force in 1986, and the Protocol to the African Charter on Human and People's Rights on the Rights of Women in Africa (the Protocol), which entered into force in 2005. The Protocol situates sexual health and rights

4 Ibidapo-Obe A A synthesis of African law (2005) 262.

5 Durham C 'Perspectives on religious liberty: A comparative framework' in Van der Vyver J D \& Witte J Jr (eds) Religious human rights in global perspective: Legal perspectives (1996) 12.

618 December 1979, G.A. Res 34/180 (entered into force 3 September 1981). The United Nations Charter (Article 1(3)), UDHR (Article 2), ICCPR and ICESCR generally prohibit discrimination on various grounds, including sex. CEDAW is more specific on gender-based discrimination and women's equality. 
within the recognition of women's reproductive rights as human rights. The adoption of the Protocol signified a renewed political commitment to the advancement of women's rights as human rights in Africa, and reinforces international law on women's equality. Its main significance lies in its affirmation of women's reproductive rights as human rights, its articulation of women's rights within an African context, and in the legal pressure it exerts on governments and State parties. The following sections review the landmark provisions of these two principal regional treaties on human and sexual rights for women in Africa.

\section{TREATY OBLIGATIONS ON WOMEN'S RIGHTS IN AFRICA}

The 'women's rights are human rights' slogan is founded on a basic truth: that the full and equal enjoyment of rights and freedoms by women and girls should be a priority for governments and United Nations agencies. In this respect the international human rights movement is ethically and ontologically geared to the moral conviction that men and women have equal rights by virtue of their humanity. As Machan acknowledges, 'the idea of human rights implies that certain unifying principles of social conduct based on our understanding of what it is to be human, deserves systematic protection by legal enforcement'. ${ }^{7}$ The notion of women's rights as human rights, therefore, not only expands the scope of international law, but also allows women the possibility of making legal claims. However, the debate over women's human rights issues continues to raise complex and controversial questions surrounding the applicability and relevance of women's rights in different legal, cultural, political and economic environments. Despite these challenges, treaty obligations remain a critical indicator of the capacity of national legal systems to protect women from violations and human rights abuses in their various domiciliary systems. Below is a consideration of the African Charter and the Protocol.

\subsection{The African Charter}

In 1981 the Assembly of Heads of State and Government of the Organization of African Unity adopted the African Charter. ${ }^{8}$ It entered into force in 1986. Although the African Charter is the primary treaty providing a framework for human rights in the region, its provisions on women's rights are largely seen as ineffective and inadequate. ${ }^{9}$ This Treaty has been domesticated and made

7 Machan T 'Human rights reaffirmed' (1994) 69 Philosophy 479-490.

827 June 27 1981, OAU Doc CAB/LEG/67/3 rev 5, 21 ILM 58, Art 18(3) (1982), entered into force 21 October 1986.

9 Every country on the continent has ratified the African Charter. 
part of many African municipal laws, including Nigeria. ${ }^{10}$ It has been ratified by every country on the continent, and legally obligates every African state to respect, promote and fulfil the rights guaranteed to African women. Articles 2 and 18(3) of the African Charter deal specifically with gender issues, and prohibit discrimination on grounds of sex. ${ }^{11}$ In particular, the African Charter obliges the African Commission on Human and Peoples' Rights to establish a collaborative relationship with CEDAW, and eliminate all forms of discrimination against women, as stipulated in international declarations and conventions.

The African Charter 'guarantees' the equal rights of women by requiring states to 'eliminate every discrimination against women' and to protect women's rights enumerated in international human rights instruments. ${ }^{12}$ It also requires states to assist families as the 'custodians of morals and traditional values'. ${ }^{13}$ Unfortunately, many have read this provision as implying a containment of the cultural view of women as inferior and subordinate to men, including, the discriminatory treatment of women in marriage, property ownership and inheritance, and the disproportionately heavy labour of women in the private spheres. In Africa some of the most serious violations of women's rights take place in the private sphere of the family, and are reinforced by traditional norms and cultural values. ${ }^{14}$

It is also significant that only one out of the more than 60 Articles in the African Charter makes specific reference to women. The only direct reference to women's rights in the Charter is contained in a clause concerning 'the family and [upholding] tradition', thereby reproducing the essential tension

10 The African Charter was ratified by Nigeria on 17 March 1983 and incorporated as the African Charter on Human and Peoples' Rights (Ratification and Enforcement) Act, Cap 10, Laws of the Federation of Nigeria 1990. In Gani Fawehinmi $v$ Abacha [1996] 9 NWLR (Pt 475) 710 it was held that 'Nigeria having promulgated Cap10 was obliged to fulfill her international obligations and that the provisions of the Charter cannot therefore ...... be inferior to decrees because government will not be allowed to contract out by local legislation, its international obligations'.

11 Article 18(3) stipulates: 'The State shall ensure the elimination of every discrimination against women and also ensure the protection of the rights of the woman and the child as stipulated in international declarations and conventions.' Article 2 provides: 'Every individual shall be entitled to the enjoyment of the rights and freedom recognized and guaranteed in the present Charter without distinction of any kind such as race, ethnic group, colour, sex, language, religion, political or any other opinion, national and social origin, fortune, birth or other status.' Article 3 states that every individual shall be equal before the law and entitled to equal protection of the law. See further Aniekwu NI 'Before Beijing and beyond - A reflection on the emergence of women's rights as human rights' (2005) 1 KNUST Law Journal 2.

12 Article 18(3) requires State parties to 'ensure the elimination of every discrimination against women and also ensure the protection of the rights of the woman and the child as stipulated in international declarations and conventions'. Article 2 provides that the rights and freedoms enshrined in the Charter shall be enjoyed by all, irrespective of race, ethnic group, colour, sex, language, national and social origin, economic status, birth or other status. Article 3 states that every individual shall be equal before the law and be entitled to equal protection of the law.

13 Articles 17(3) states: 'The promotion and protection of morals and traditional values recognised by the community shall be the duty of the state.'

14 Adjetey FN-A 'Religious and cultural rights: Reclaiming the African women's individuality: The struggle between women's reproductive autonomy and African society and culture' (1995) 44 American University Law Review 1376. For the African woman the most severe violations of her human rights are rooted deeply within the family system, bolstered by community norms of male privilege, and frequently justified by religious doctrines or appeals to custom or tradition. 
that plagues the realisation of women's rights in Africa. ${ }^{15}$ Indeed, the African Charter has been interpreted to protect customary and religious laws that violate women's rights, such as, the rights to equality and non-discrimination; security of the person; and protection from cruel, inhuman and degrading treatment. ${ }^{16}$ It should be noted that different countries have interpreted their obligations under the African Charter in different ways.

The following are the key shortcomings of the Treaty as it pertains to women:

- its failure to explicitly define discrimination against women; $;^{17}$

- its lack of guarantees for the rights to consent to marriage and equality in marriage; and

- its emphasis on traditional values and practices that have long impeded the advancement of women's rights in Africa. ${ }^{18}$

In the Botswana case of Attorney-General $v$ Unity Dow, the court used the principles espoused in the African Charter to override traditional customs of unequal treatment of women in respect of their citizenship rights. ${ }^{19}$ However, it observed that the language of the African Charter 'did not guarantee progressive interpretation of women's rights in the region'.$^{20}$ The constitutions of many African countries, including those of Kenya, Zimbabwe and Zambia, maintain special provision for personal and customary law systems, often to the disadvantage of women attempting to exercise their right to equality in the family and society. The application of Shari'a laws in Northern Nigeria provides another example of the use of customary or religious laws that seem to compromise the rights of equality and non-discrimination under international law.

In a ruling by the Zimbabwean Supreme Court in Magaya $v$ Magaya, the court held that domestic laws (that discriminated against women) carried greater weight than international instruments that protect women from discrimination. ${ }^{21}$ In considering whether a woman could inherit her father's estate, the court relied on traditional conceptions of the family and the male patriarch as stipulated under the African Charter, rather than on the rights and standards guaranteed under international law. ${ }^{22}$

15 The Protocol responds to the need to reinforce Articles 17 and 27 with a more elaborate rendering of the respect for women's human rights. Article 27(1) of the African Charter had earlier provided that 'every individual shall have duties towards his family and society'.

16 Adjetey F N-A (n 14 above).

17 Adjetey F N-A (n 14 above) notes that the Charter 'leaves room for ambiguity in the interpretation of what constitutes prohibited discrimination'. The reference to cultural values requires definition, and the questions of which traditional values are recognised by the community, and who makes that determination, leave a lot of uncertainty in the interpretation of the rights in the Charter.

18 'Women in Law and Development in Africa (WiLDAF) News', available at http://site.mweb.co.zw/ widaf/news5.html (last visited 18 December 2007).

19 Attorney-General v Unity Dow 1994 (6) BCLR 1 (Botswana).

20 Attorney-General $v$ Unity Dow (n 19 above) 65.

21 Venia Magaya v Nakayi Shonhiwa Magaya 1999 (1) ZLR 100 (S).

22 Venia Magaya v Nakayi Shonhiwa Magaya (n 21 above). 
Advocates for women's rights recognised these weaknesses and sought to address them by adopting an Additional Protocol that focused solely on women's rights in Africa. In April 1997 a Draft Protocol was created, which was finally adopted some six years later. ${ }^{23}$ In September 1997, the African region developed a regional strategy on reproductive health, with member states committing themselves to "implement the reproductive health and rights concept for the next twenty five years' ${ }^{24}$ The vision is that within this period, 'all women in the region should enjoy an improved quality of life through a significant reduction of maternal and neonatal morbidity, unwanted pregnancy and sexually transmitted infections including HIV/AIDS, and the elimination of harmful practices and sexual violence'. ${ }^{25}$

On 11 July 2003 the Additional Protocol on Women's Rights to the African Charter was adopted by the African Union, which replaced the Organization of African Unity, in Maputo, Mozambique. It entered into force in 2005.26 This Protocol, which was adopted to supplement the regional human rights charter (the African Charter), was a direct response to women's needs, and sets out specific standards and measures by which women's rights should be recognised and protected. ${ }^{27}$ The document especially contains provisions on the elimination of harmful traditional and cultural practices that impede the realisation of women's rights on the continent. ${ }^{28}$ Currently, most African countries, including Nigeria, have ratified the Protocol.

\subsection{The Protocol ${ }^{29}$}

The significance and potential of the Protocol go well beyond Africa. The adoption of the Protocol signifies a renewed political commitment to the advancement of women's rights as human rights in Africa, and reinforces international law on women's equality. ${ }^{30}$ It affirms reproductive choice and autonomy as key human rights, and contains a number of global firsts. For example, it represents the first time that an international human rights treaty has explicitly articulated a woman's right to abortion when pregnancy results from sexual assault, rape or incest; when continuation of the pregnancy endangers the life or health of the pregnant woman; and in cases of grave foetal defects that are incompatible with life. ${ }^{31}$ Another first is the Protocol's

23 Draft Protocol to the African Charter on Human and Peoples' Rights (April 1997).

24 African Regional Strategy on Reproductive Health part 1 (1997).

25 African Regional Strategy on Reproductive Health (n 24 above) part 2(1)a.

26 Adopted on 11 July 2003 at the 2nd Ordinary Session, Assembly of the Union.

27 The Protocol is charged with 'supplementing' the regional human rights charter, the African Charter, and provides specific protection for women's human rights, including sexual and reproductive rights. See Articles 3 - 11.

28 The Protocol states that State parties shall commit themselves to achieving the elimination of harmful cultural and traditional practices and all other practices which are based on the idea of the inferiority or superiority of either of the sexes, or on stereotyped roles for women and men.

29 See the Protocol (n 28 above).

30 Most of CEDAW's obligations and guarantees on women's rights are duplicated in the Protocol, but with special reference to African women. See further, Aniekwu N I 'The Convention on the Elimination of All Forms of Discrimination against Women and the status of implementation on the right to health care in Nigeria'13 Human Rights Brief (American University College of Law).

31 Article 14(2). 
call for the prohibition of harmful traditional practices, including female circumcision or female genital mutilation.

As the Protocol notes, 'despite the ratification of the African Charter, women in Africa still continue to be victims of discrimination and harmful practices'. ${ }^{32}$ The Protocol's significance lies in its affirmation of women's reproductive rights as human rights, its articulation of women's rights within an African context, and in the legal pressure it exerts on governments and State parties. In attempting to re-invigorate the African Charter's commitment to women's equality, the Protocol adds specific rights that were missing from the African Charter, and clarifies governments' obligations with respect to gender-specific human rights..$^{33}$ It can, therefore, be said to be based on the region's shared legal, political, socio-economic and intellectual traditions. ${ }^{34}$ The Protocol presents a tremendous opportunity for women's rights in Africa, with detailed provisions that can enable African women to realise and exercise their sexual rights. We now consider key women's rights provisions in the Protocol.

\subsubsection{Reproductive choice}

There are key reproductive rights protections in the Protocol within the context of existing international protections for women. ${ }^{35}$ The Protocol is the first legally binding human rights instrument to expressly articulate women's reproductive rights as human rights, and to guarantee a woman's right to reproductive choice and autonomy. ${ }^{36}$ It also provides a more detailed articulation than earlier global human rights protecting a woman's right to reproductive health and family planning services. Existing standards recognise women's rights to 'the highest attainable standard of health' and to equality in 'access to health care services, including those related to family planning' ${ }^{37}$ The Protocol thus affirms women's right to reproductive choice and autonomy, and clarifies African states' duties in relation to women's sexual and reproductive

32 Preamble to the Protocol.

33 Preamble to the Protocol. See also Aniekwu N I 'Converging constructions: A historical perspective on sexuality and feminism in post-colonial Africa'(2006) 10 African Sociological Review 143 which identifies the male dominated patterns of subjecthood and dominance in African cultures, especially in post-colonial territories, and the pattern of discrimination in the private domain/sphere that seem to characterise the language of 'preserving cultural norms' as seen in the African Charter.

34 Mugwagwa G W 'Realizing universal human rights norms through regional human rights mechanisms: Reinvigorating the African system' (1999) 10 Indiana International \& Comparative Law Review $41-42$.

35 Article 14 states: 'States Parties shall ensure that the right to health of women, including sexual and reproductive health, is respected and promoted. This includes (a) the right to control their fertility; (b) the right to decide whether to have children, the number of children and the spacing of children; (c) the right to choose any method of contraception;...' These are standards in the global human rights treaties that are applicable in the African region by reason of their ratification by various African State parties. The pre-existing treaty provisions for women are mostly found in CEDAW. They, however, do not have any specific regional focus.

36 Article 14 is entitled 'Health and Reproductive Rights', and also contains provisions protecting women against STDs and HIV/AIDS, and relating to sex education.

37 See Art 12(1) CEDAW. In 'Treaty obligations: The United Nations Charter and International Bill of Rights revisited'(unpublished), I compare the provisions of the International Bill of Rights with the language of the Protocol, and argue that customary and traditional practices cannot prevail over the rights of women, despite the tacit endorsement of cultural norms and values in the African Charter. 
health. CEDAW, additionally, guarantees women's rights to 'appropriate services in connection with pregnancy', to 'decide freely and responsibly on the number and spacing of their children', and 'to have access to the information, education and means to enable them to exercise these rights'. ${ }^{38}$

\subsubsection{Abortion}

The Protocol is the first human rights instrument to expressly articulate a woman's right to abortion in specified circumstances. ${ }^{39}$ No other human rights treaty had explicitly articulated a woman's right to abortion. The Human Rights Committee, the treaty monitoring body that supervises government compliance with the ICCPR, had previously interpreted existing global human rights standards to guarantee a woman's right to safe and legal abortion under certain circumstances pertaining to the interpretation of stated rights to equality, non-discrimination, life, liberty, security of the person, and the highest attainable standard of health. ${ }^{40}$ The CEDAW Committee, the treaty monitoring body that monitors government compliance with CEDAW, has also framed the issue of maternal mortality due to unsafe abortions as a violation of a woman's right to life. ${ }^{41}$

\subsubsection{HIV/AIDS}

The Protocol is the first treaty to specifically address women's rights in relation to HIV/AIDS in Africa, and identify protection from HIV/AIDS as a key component of women's sexual and reproductive rights. In addition to guaranteeing a woman's right to protection from sexually transmissible infections, including HIV/AIDS, the Protocol guarantees women's right to adequate, affordable and accessible health services. ${ }^{42}$ It also articulates a state's duty to

38 Article 16(1)(e) CEDAW.

39 Article 14(2)(c) states: 'States Parties shall take all appropriate measures to: ...protect the reproductive rights of women by authorising medical abortion in cases of sexual assault, rape, incest, and where the continued pregnancy endangers the mental and physical health of the mother or the life of the mother or of the foetus.'

40 See, for example, the Concluding Observations of the Human Rights Committee that discusses how women compelled to seek illegal abortions experience a violation of Article 6 of the ICCPR; the right to life. See also Concluding Observations of the Human Rights Committee: Senegal, 61st Sess para 12 UN Doc CCPR/C/79/Add.82 (1997); Concluding Observations of the Human Rights Committee: Sudan, HRC 61st Sess 1642nd mtg para 10 UN Doc CCPR/C/79/Add 85 (1997); Concluding Observations of the Human Rights Committee: Tanzania, HRC 63RD Sess 1697th mtg para 15 UN Doc CCPR/C/79/Add 97 (1998). See also HRC General Comment No 28: Equality of rights between men and women (Art 3) 68th Sess para 10 UN Doc CCPR/C/21/Rev 1/Add 10 (2000), in Compilation of General Comments and General Recommendations adopted by human rights treaty bodies (UN Doc HRI/GEN/1/Rev 1) (2003) 179.

41 The CEDAW Committee has commented on the issue of maternal mortality due to unsafe abortion in numerous sets of Concluding Observations, consistently criticising restrictive abortion laws, and asking State parties to review legislation making abortion illegal. There are a number of Concluding Observations by the CEDAW Committee in respect of African countries, including, Burundi, Morocco, Namibia, Zimbabwe, Burkina Faso, and Cameroon, on this issue. See e.g. Concluding Observations of the Committee on the Elimination of Discrimination Against Women: Burundi, CEDAW 24th Sess 488 - 489th 496th mtgs para 61, U.N. Doc. A/56/38 (2001); Concluding Observations of the Committee on the Elimination of Discrimination Against Women: Madagascar, CEDAW 49th Sess 236 237th mtgs para 244 UN Doc A/49/38 (2004).

42 Articles 14(1)(d) and (2)(a) of the Protocol. 
protect girls and women from practices and situations that increase their risks of infection, such as, child marriage, wartime sexual violence, and female genital mutilation. ${ }^{43}$ This obligation obviously stems from the fact that women account for more than half of infected persons in sub-Saharan Africa. ${ }^{44}$

HIV/AIDS is not expressly mentioned in any earlier global or regional human rights treaty. Existing global human rights standards on the right to equality, to the highest attainable standard of health, and to life, have all been interpreted to indirectly guarantee women's rights in relation to HIV/ AIDS. For example, the CEDAW Committee has acknowledged that inequality and discrimination against girls and women play a role in making women more vulnerable to HIV infection, and the Committee has asked governments to adopt a human rights based approach to HIV/AIDS. ${ }^{45}$ However, no global human rights instrument, other than the Protocol, had expressly articulated the standards governing women's rights and states' duties in relation to the HIV/AIDS pandemic.

\subsubsection{Violence against women}

The Protocol has defined 'violence against women' to mean:

'all acts perpetrated against women which cause or could cause them physical, sexual, psychological and economic harm, including the threat to take such acts; or to undertake the imposition of arbitrary restrictions on or deprivation of fundamental freedoms in private or public life in peace time and during situations of armed conflicts or of war'. ${ }^{46}$

The Protocol goes beyond existing global and regional treaties by specifying legal protection against gender-based violence, in both the public and private spheres. It significantly advances women's rights by relocating every day abuses in the private sphere of the home to the public realm of violations for which states must be held accountable. The Protocol is also unique in its express guarantee of a woman's right to be protected from threats of physical and verbal violence.

None of the existing global human rights treaties defined or openly addressed violence against women ${ }^{47}$ This gap in the protection afforded to women was, in part, due to a historic legal distinction between rights violations that occur in the public sphere and those that occur in the private sphere. Until recently, the so-called 'private' violence of domestic abuse, marital rape and harmful

43 Articles 5, 6 and 11 of the Protocol. No other global human rights instrument has expressly articulated governing women's rights and a state's duties in relation to the AIDS pandemic. Existing global standards on the right to equality, to the highest attainable standard of health, and to life, have all been interpreted to indirectly guarantee women's rights in relation to AIDS. For example, the CEDAW Committee has acknowledged that inequality and discrimination against girls and women play a role in making women more vulnerable to HIV infection, and the Committee has asked governments to adopt a human rights based approach to AIDS. See Concluding Observations of the Committee on the Elimination of Discrimination Against Women: Egypt, CEDAW 24th Sess 492 - 493rd mtgs paras 336 - 337 UN Doc A/56/38 (2001).

44 Aniekwu N I \& Atsenuwa A 'Sexual violence and HIV/AIDS: An intimate link'(2007) 12 Local Environment: The International Journal of Justice and Sustainability 315.

45 CEDAW Committee, General Recommendation 24 para 18.

46 Articles 3(4) and 4(2)(a).

47 While no international treaty explicitly addresses violence against women, the Convention of Belem do Para, an Inter-American regional human rights treaty, does so. 
traditional practices escaped specific mention and legal scrutiny under international, regional and national laws. The CRC requires states to 'protect the child from all forms of physical or mental violence, injury or abuse, neglect or negligent treatment, maltreatment or exploitation'. ${ }^{48}$ However, this provision is expressed in gender-neutral terms, and does not recognise the particular vulnerability of girls and female adolescents to violence, nor does it articulate specific state obligations in relation to gender-based violence.

Probably in an attempt to protect women from gender-based violence, subsequent global instruments; those guaranteeing the rights to equality, non - discrimination, life, liberty, security of the person, and the highest attainable standard of health, have been interpreted to include a woman's right to be protected from violence. For example, in its General Recommendation on Violence against Women, the CEDAW Committee states that '[t]he definition of discrimination includes gender-based violence [...]. It includes acts that inflict physical, mental or sexual harm or suffering, threats of such acts, coercion and other deprivations of liberty'. ${ }^{49}$ The Human Rights Committee has also identified domestic violence and sexual violence as violations of a woman's right to be free from torture and other cruel, inhuman or degrading treatment. $^{50}$

\subsubsection{Harmful traditional practices}

\section{'Harmful practices' means:}

'all behaviour, attitudes and or practices which negatively affect the fundamental rights of women and girls, such as their right to life, health, dignity, education and physical integrity .... State Parties shall prohibit and condemn all forms of harmful practices which negatively affect the human rights of women and which are contrary to recognized international standards. State Parties shall take all necessary legislative and other measures to eliminate such practices. ${ }^{51}$

The Protocol affirms and reinforces the language of CEDAW, which also requires State parties to take all appropriate steps to eliminate social and cultural patterns and practices that are discriminatory to women. ${ }^{52}$ Other global standards guaranteeing the rights to life, liberty, security of the person, and health have also been interpreted to include a woman's right to be protected

48 Article 19(1) CRC. Article 34 CRC further requires states to 'protect the child from all forms of sexual exploitation and sexual abuse'. (CRC adopted 20 November 1989 GA Res 44/25 Annex UN GAOR 44th Sess Supp No 49 at 167) The Child Rights Act of Nigeria duplicates many of the provisions of the CRC, and has been adopted by some state legislatures in the country, including Edo state.

49 CEDAW General Recommendation 19 on Violence Against Women 11th Sess para 6 UN Doc $\mathrm{A} / 47 / 38$ (1999) in Compilation of General Comments and General Recommendations (n 40 above) (Rev 6) 243.

50 Human Rights Committee General Comment No 28: Equality of rights between men and women (Art 3) 68th Sess para 11 UN Doc CCPR/C/21/Rev 1/Add 10 (2000) in Compilation of General Comments and General Recommendations (n 40 above) (Rev 1) 168.

51 Articles $1(\mathrm{~g})$ and 5(2) of the Protocol.

52 Article 5(a) CEDAW states: 'States Parties shall take all appropriate measures:... to modify the social and cultural patterns of conduct of men and women, with a view to achieving the elimination of prejudices and customary and all other practices which are based on the idea of the inferiority or the superiority of either of the sexes or on stereotyped roles for men and women.' 
from harmful practices. ${ }^{53}$ However, in a significant advancement of women's sexual and reproductive rights, the Protocol goes further than pre-existing treaties in requiring states to prohibit, through legislative measures backed by sanctions, all forms of female genital mutilation. ${ }^{54}$ The language of the Protocol also does not allow for a cultural defence of female circumcision/ female genital mutilation, whereas the African Charter arguably does. ${ }^{55}$

The Protocol's provisions on harmful practices should lay to rest arguments that customary and traditional practices can prevail over the rights of women under the African Charter. In the latter document the lack of specificity on discrimination against women left them vulnerable to arguments that 'cultural values' and 'community norms' can prevail over human rights abuses, even when physical and psychological harm results. The Protocol requires states to eliminate cultural and traditional practices that discriminate against women, and further provides that 'women shall have the right to live in a positive cultural context and to participate at all levels in the determination of cultural policies'. ${ }^{56}$ In this respect the Protocol makes clear what the African Charter omitted, viz, that customary law and tradition ends where discrimination against women begins.

\section{CONCLUSION}

Universal and regional views of human rights are centrally concerned with the interplay between society and the state, exploring ways in which society constructs and limits human rights and gendered individuals. Implicit in this assumption is the claim that societal norms, language and law are merely products of human will and actions, and are constantly evolving to meet the demands and needs of contemporary times. Also connected with this view is the notion that cultural norms function as a source of power and control within modern society. Culture itself becomes a source of control and a form of power that often becomes a site of resistance for women's rights activists. ${ }^{57}$ It is also precisely this model of power that universal human rights standards are designed to regulate in order to prevent discrimination. In this regard one critical question is: whether the activities of CEDAW, generally regarded as the international bill of rights for women, have made a meaningful contribu-

53 Article 24(3) CRC requires states to take all appropriate measures 'with a view to abolishing traditional practices prejudicial to the health of children'. The African Charter on the Rights and Welfare of the Child in Art 21(1) requires states to 'take all appropriate measures to eliminate harmful social and cultural practices affecting the welfare, dignity, normal growth and development of the child...'

54 Article 5(b) of the Protocol.

55 Article 18(3) of the African Charter provides: 'The State shall ensure the elimination of every discrimination against women and also ensure the protection of the rights of the woman and the child as stipulated in international declarations and conventions.' Article 17(2) of the African Charter provides: 'Every individual may freely, take part in the cultural life of is community.' Together these provisions may be interpreted and applied to permit cultural defences to traditional practices harmful to women.

56 Article 17(1) of the Protocol.

57 Higgins T 'Anti-essentialism, relativism and human rights,' (1996)19 Harvard Women's Law Journal 89. See further, Aniekwu N I (n 33 above) in which it is reiterated that the concept of culture, especially as it pertains to human rights protection and cultural relativism, possesses a shifting paradigm in meaning and nomenclature. 
tion to the pursuit of health and rights for women at the national, regional and local levels in African legal systems. ${ }^{58}$

The impact of an international instrument like CEDAW applied in New York may seem a long way from women's lives in Africa, and it will be rare that the work of the CEDAW Committee has an immediate and direct effect on African women. Rather, it is through law making, judicial decisions, regional documents and policies that women's rights issues propagated by CEDAW and conferences like Beijing, can help to make a difference to women's lives in Africa. The strain under which the treaty system as a whole is operating, the need to collaborate with, and influence, legal bodies to incorporate gender in human rights advocacy, case decisions, law reform and other work, all continue to pose challenges throughout the region. ${ }^{59}$ However, an impact on women's rights seems to have been made by the adoption of the Protocol.

From the foregoing it is clear that the provisions of the Protocol are an indication that African governments have the capacity and willingness to realise, respect and protect the sexuality and rights of women in their various territories. Granted, the constituents of community, culture and ethnicity, and their interlinking with gender, are crucial to discourses on sexuality and rights on the African continent, especially the sub-Saharan region. ${ }^{60}$ However, it must always be remembered that the potentials and politics of multi-culturalism and multi-ethnicity in African societies are, in themselves, chief mechanisms that 'claw back' the success of the entire human rights paradigm. In this author's view, the African Charter and the Protocol are pro-active regional treaties and legal documents that affirm the readiness of African territories to protect the sexual health and rights of their citizens. The gendered nature of the Protocol is further indication that cultural stereotypes in the region should only be 'respected' in so far as customs and traditions do not directly or indirectly infringe on the sexual health and rights of African women. In an era where issues of cultural relativity and universalism have taken centre stage in international humanitarian law, and debates on the applicability and relevance of women's rights continue to rage in academic circles, the very essence and fabric of human rights for women have often been threatened. The adoption of an African Protocol on Women's Rights is a happy indication that there is hope for the legal protection and recognition of gender-specific human rights in African municipal systems. Indeed, the document could not have been adopted at a better time.

\section{BIBLIOGRAPHY}

Adjetey F N-A 'Religious and cultural rights: Reclaiming the African women's individuality: The struggle between women's reproductive autonomy and

\footnotetext{
58 Aniekwu N I 'Treaty Obligations: A look at the Protocol to the African Charter on Human and Peoples' Rights' (Presentation made at the African Gender Institute, University of Cape Town, 24 November 2007).

59 Aniekwu N I (n 58 above) 3.

60 See Schneider H K The Africans: An ethnological account (1981) 134.
} 


\section{THE ADDITIONAL PROTOCOL TO THE AFRICAN CHARTER}

African society and culture' (1995) 44 American University Law Review 1351

Aniekwu N I \& Atsenuwa A 'Sexual violence and HIV/AIDS: An intimate link' (2007) 12 Local Environment: The International Journal of Justice and Sustainability

Aniekwu N I 'Before Beijing and beyond - A reflection on the emergence of women's rights as human rights' (2005) 1 KNUST Law Journal

Aniekwu N I 'Converging constructions: A historical perspective on sexuality and feminism in post-colonial Africa' (2006) 10 African Sociological Review

Aniekwu N I 'The Convention on the Elimination of All Forms of Discrimination against Women and the status of implementation on the right to health care in Nigeria' 13 Human Rights Brief (American University College of Law)

Aniekwu N I 'Treaty obligations: A look at the Protocol to the African Charter on Human and Peoples' Rights' (2007 presentation at the African Gender Institute, University of Cape Town)

Cook R ' Reservations to the Convention on the Elimination of All Forms of Discrimination against Women' (1990) 30 Virginia Journal of International Law 643

Durham C 'Perspectives on religious liberty: A comparative framework' in Van der Vyver J D \& Witte J Jr (eds) Religious human rights in global perspective: Legal perspectives (1996)

Higgins T 'Anti-essentialism, relativism and human rights' (1996) 19 Harvard Women's Law Journal

Ibidapo-Obe A A synthesis of African law (2005) Nigeria: Concept Publications Limited

Macham T 'Human rights reaffirmed' (1994) 69 Philosophy

Mugwagwa G W'Realizing universal human rights norms through regional human rights mechanisms: Reinvigorating the African system' (1999) 10 Indiana International and Comparative Law Review 35

Schneider H K The Africans: An ethnological account (1981) New Jersey: Prentice Hall

Steiner $\mathrm{H} \mathrm{J} \&$ Alson P International human rights in context: Law, politics and morals (2000) Oxford: Oxford University Press

United Nations Compilation of General Comments and General Recommendations adopted by human rights treaty bodies (UN Doc HR1/GEN/1) 